\title{
Changing climate alters inputs and pathways of mercury deposition to forested ecosystems
}

\author{
Bradley D. Blackwell • Charles T. Driscoll • \\ John A. Maxwell • Thomas M. Holsen
}

Received: 18 September 2013/Accepted: 22 January 2014/Published online: 21 February 2014

(C) The Author(s) 2014. This article is published with open access at Springerlink.com

\begin{abstract}
Although land cover and meteorological conditions are known to impact mercury ( $\mathrm{Hg}$ ) deposition processes, few studies have addressed how changes in forest cover and shifting climatic conditions will impact the $\mathrm{Hg}$ cycle. The purpose of this study was to examine the effects of forest type (hardwood vs. conifer) and meteorological variation on atmospheric $\mathrm{Hg}$ deposition in two forest stands in Huntington Wildlife Forest in upstate New York, USA. Mercury deposition associated with litterfall was similar between the hardwood and conifer stands,
\end{abstract}

Responsible Editor: Jan Mulder

Electronic supplementary material The online version of this article (doi:10.1007/s10533-014-9961-6) contains supplementary material, which is available to authorized users.

B. D. Blackwell $(\bowtie) \cdot$ C. T. Driscoll

Department of Civil and Environmental Engineering,

Syracuse University, 151 Link Hall, Syracuse, NY 13244,

USA

e-mail: bradleydouglas@gmail.com

C. T. Driscoll

e-mail: ctdrisco@syr.edu

\section{J. A. Maxwell · T. M. Holsen}

Department of Civil and Environmental Engineering,

Clarkson University, 8 Clarkson Avenue, Potsdam,

NY 13699, USA

e-mail: maxwelj@clarkson.edu

T. M. Holsen

e-mail: holsen@clarkson.edu but total $\mathrm{Hg}$ deposition was greater in the coniferous stand due to larger throughfall $\mathrm{Hg}$. Soil evasion losses of $\mathrm{Hg}$ were significantly higher in the hardwood plot. Although $\mathrm{Hg}$ deposition was greater and evasion losses were lower in the conifer plot, soil $\mathrm{Hg}$ pools were smaller than in the hardwood plot. Annual variability in meteorological conditions was substantial between 2009 and 2010, and changes in $\mathrm{Hg}$ deposition over this period appear to be related to variation in temperature and precipitation quantity. The results from this study suggest that projected increases in temperature and precipitation in the northeastern United States could alter $\mathrm{Hg}$ deposition and availability by decreasing litterfall $\mathrm{Hg}$ inputs and increasing throughfall $\mathrm{Hg}$ inputs.

Keywords Mercury - Atmospheric .

Deposition · Throughfall · Litterfall

\section{Introduction}

Mercury $(\mathrm{Hg}$ ) contamination is an environmental issue that impacts ecosystems across the globe, even in remote, pristine locations (Fitzgerald et al.1998; Driscoll et al. 2013). Despite the fact that $\mathrm{Hg}$ is ranked as one of the top priority pollutants in the United States (http://www.atsdr.cdc.gov/SPL/index.html), approximately 60 tons are still emitted annually, largely through various industrial processes in the United States (Schmeltz et al. 2011). Although Hg emissions 
and deposition in North America have declined since the mid-1980s, global emissions are increasing and many ecosystems experience symptoms of $\mathrm{Hg}$ contamination (Driscoll et al. 2013; Drevnick et al. 2012; Schmeltz et al. 2011). The global biogeochemical cycle of $\mathrm{Hg}$ is dynamic and complex as $\mathrm{Hg}$ can be readily transported through the atmosphere and cycle through terrestrial and aquatic ecosystems. Production of methyl-mercury (MeHg) largely takes place in reducing environments, and it subsequently biomagnifies and bioaccumulates in aquatic food chains (Wiener et al. 2003). As human and wildlife exposure to $\mathrm{Hg}$ occurs primarily through consumption of $\mathrm{MeHg}$ contaminated fish and shellfish, past research has mainly focused on aquatic environments. However, freshwater ecosystems occupy less than $3 \%$ of total land cover in North America. Forest is the predominant land cover category in North America and likely receives greater atmospheric $\mathrm{Hg}$ deposition than any other land cover category.

Mercury accumulates in leaf and needle tissues, resulting in a large flux of $\mathrm{Hg}$ to the forest floor during litterfall (Risch et al. 2012a; Bushey et al. 2008; Rea et al. 1996). Both field and experimental studies suggest that $\mathrm{Hg}$ deposited via litterfall is derived almost completely from atmospheric sources (Ericksen et al. 2003; Rea et al. 2001). In addition, leaf and needle surfaces adsorb reactive atmospheric $\mathrm{Hg}$ species that are washed off during rain events, leading to elevated deposition of $\mathrm{Hg}$ in throughfall beneath a forest canopy compared to open precipitation samples (Graydon et al. 2008; Rea et al. 2001; Kolka et al. 1999). While forest cover clearly influences $\mathrm{Hg}$ deposition processes, there has been little research on variability of atmospheric $\mathrm{Hg}$ deposition across different forested landscapes. Evidence suggests that the structure of forest stands (i.e., hardwood vs. conifer) impacts $\mathrm{Hg}$ deposition processes (Obrist et al. 2012; Witt et al. 2009; Demers et al. 2007; Sheehan et al. 2006).

While meteorological variables influence $\mathrm{Hg}$ deposition, to date the impact of climate change on $\mathrm{Hg}$ cycling processes has received little consideration in the literature (Jacob and Winner 2009). Average temperatures are expected to increase over the next century in forests of the Northeastern United States, and precipitation is also expected to increase and become more variable (Hayhoe et al. 2008; Plummer et al. 2006). These changes are expected to increase transpiration rates and water stress and alter physiological processes within forest ecosystems (Pourmokhtarian et al. 2012). Changes in watershed processes brought about by climate change are likely to alter not only total $\mathrm{Hg}$ deposition but also the pathways of $\mathrm{Hg}$ deposition in forests and subsequent transport, fate and bioaccumulation.

The overall goal of this study was to quantify, compare, and contrast different pathways of $\mathrm{Hg}$ deposition to hardwood and conifer forests in the Adirondack Park and to estimate storage of $\mathrm{Hg}$ in soil profiles. Because this study spanned two years, we also evaluated how changing meteorological conditions affected inter-annual variability in $\mathrm{Hg}$ deposition. To our knowledge, this is the first field study to demonstrate that meteorological variation (and potential change in climate) directly impacts $\mathrm{Hg}$ deposition processes in forested ecosystems.

\section{Materials and methods}

\section{Study site}

The present study was conducted at Huntington Wildlife Forest (HWF) in New York State $\left(43.97^{\circ} \mathrm{N}\right.$, $74.22^{\circ} \mathrm{W}$ ). The 6,000 ha forest is located in the central portion of Adirondack Park near Newcomb, NY (Fig. 1). The forest has been the site of numerous biogeochemical studies (e.g., Selvendiran et al. 2008; Mitchell et al. 1992; Johnson and Lindberg 1992), and serves as a monitoring station for the National Atmospheric Deposition Program (NADP) National Trends Network (NTN), Mercury Deposition Network (MDN), and EPA Clean Air Status and Trends Network (CASTNET) programs. Two plots were established within the HWF, one dominated by hardwood and another dominated by coniferous trees. The hardwood plot is located within Arbutus Lake watershed, and the canopy is dominated by mature sugar maple (Acer saccharum), yellow birch (Betula alleghaniensis), and American beech (Fagus grandifolia), and the understory is dominated by American beech. This plot has served as a site for previous $\mathrm{Hg}$ studies (Choi and Holsen 2009; Bushey et al. 2008). The conifer plot is located within Rich Lake watershed and consists of a canopy dominated by white pine (Pinus strobus) with interspersed balsam fir (Abies balsamea) and eastern white cedar (Thuja 
Fig. 1 Map of forest plot areas at Huntington Wildlife Forest (AEC Adirondack Ecological Center). Inset map shows forest location in upstate New York, USA

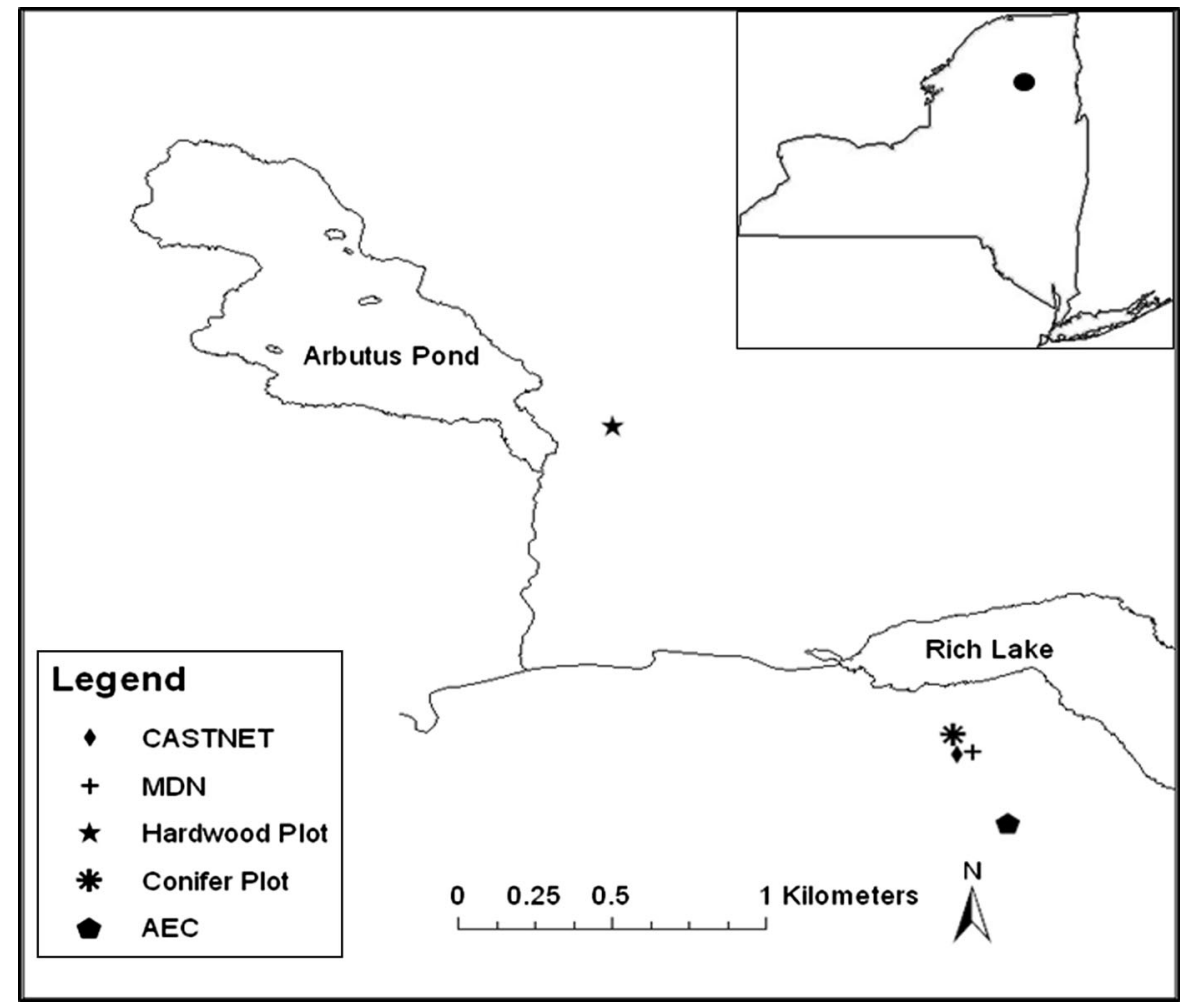

occidentalis). The understory is relatively open due to the thick canopy with only occasional understory yellow birch and sugar maple. Although the site history of the conifer stand is not fully documented, it was previously farm pasture, and after the farm was abandoned, the stand was re-vegetated with white pine. Aside from harvesting timber from a blowdown event in 1951, the conifer plot has been mostly undisturbed for the past 100 years. The two plots are approximately $2 \mathrm{~km}$ apart, and the conifer stand is directly adjacent to the NADP and MDN sampling stations. We made replicate measurements over two years $(2009,2010)$ within a plot in each stand to compare $\mathrm{Hg}$ inputs and ecosystem pools and fluxes between nearby conifer and hardwood forests.

\section{Foliar sampling}

Live foliage was sampled from dominant canopy species in both the conifer plot and hardwood plot in 2009 and 2010. Canopy foliage, defined as foliage over $10 \mathrm{~m}$ in height in direct sunlight, was sampled from 3-5 individual trees of each species on approximately a monthly basis throughout the growing season. Foliage was collected by shooting canopy branches with steel shot fired from a shotgun. Downed branches were gathered and placed in polyethylene zipper bags. All samples were frozen within $24 \mathrm{~h}$. To avoid contamination, the shotgun operator did not gather samples, but foliar samples were collected by an assistant wearing nitrile gloves.

\section{Litter collection}

Litter was collected from both plots using litter traps. The traps were constructed from plastic crates and were lined with plastic mesh. Five collectors were randomly deployed in both the conifer plot and hardwood plot. Hardwood traps were deployed only from May to December, and samples were collected from traps between mid-September and early December. Conifer traps were deployed year-round but were elevated $1.5 \mathrm{~m}$ off the ground during winter so they would remain above the snowpack. Conifer litter samples were collected monthly between June and December and again in April and May of each sampling year. 
Throughfall and precipitation sampling

Precipitation $\mathrm{Hg}$ was sampled weekly throughout the entirety of the project at Huntington Forest MDN station (NY20). More information about sampling methods of the MDN network is available at http:// nadp.sws.uiuc.edu/mdn/.

In addition to direct precipitation, throughfall samples were collected monthly during the growing seasons of 2009 and 2010. Throughfall collectors were constructed by attaching acid washed, $20 \mathrm{~cm}$ polyethylene funnels to Teflon collecting bottles using Teflon tubing. Bottles were placed in an opaque casing and charged with $10 \mathrm{~mL}$ of concentrated low- $\mathrm{Hg} \mathrm{HCl}$ to prevent microbial growth and volatilization of $\mathrm{Hg}$. Acid-washed watch glasses were placed in the opening of each funnel to prevent leaf litter and insects from entering bottles. Five collectors were randomly placed in both the hardwood and conifer plots, and bulk throughfall samples were collected over a 2-3 week period. After collection, bottles were removed and stored at $4{ }^{\circ} \mathrm{C}$ until time of analysis. Snowfall was collected during snow events by deploying large acid washed buckets overnight. The collected snow was transferred to Teflon bottles using acid-washed scoops, weighed to determine mass, and stored at $4{ }^{\circ} \mathrm{C}$ for subsequent $\mathrm{Hg}$ analysis.

Canopy interception was determined for the conifer plot by comparing throughfall collector volumes from within the plot to wet deposition volumes collected in a nearby clearing. This method was used for both rain and snow events. In addition, concentrations of $\mathrm{Hg}$ in throughfall and snowfall beneath the canopy were compared to concentrations in the open clearing. These data were used to calculate canopy enrichment factors within the conifer plot. Calculations from Choi et al. (2007)were used to calculate interception in the hardwood plot; note that Choi et al. (2007) worked within the same hardwood stand used for this study, and their calculations for canopy interception compare well with literature values of interception rates in northern hardwood forests (Risch et al. 2012b; Demers et al. 2007; Rea et al. 2001). During the leaf-off period, hardwood interception rates and $\mathrm{Hg}$ enrichment factors were assumed to be zero.

Soil profile and evasion sampling

Soil profiles were sampled, measured, and characterized by excavating two soil pits in each plot. Soil pits in the hardwood plot were excavated and characterized in 2004 (Driscoll, unpublished data). Soil pits in conifer plot were excavated in October 2008. Soils from both plots are Spodosols (Typic Haplorthod) and have similar horizons (Oa, E, Bh, Bs1, Bs2, Bs3, C). Five replicates from each horizon were collected from the undisturbed wall of each soil pit, and horizon thickness was measured. Bulk density was estimated for each horizon based on averages from an extensive study of Adirondack soils that contained multiple hardwood and pine dominated plots (Bedison 2009). Soil Hg pools were calculated by combining measurements of soil $\mathrm{Hg}$ concentrations, horizon thickness, and horizon bulk densities. Total soil profile thickness was assumed to be one meter.

Soil $\mathrm{Hg}$ evasion was measured in the conifer plot in 2010. Soil $\mathrm{Hg}$ evasion was estimated in the conifer plot using dynamic flux chambers connected to a Tekran 2537A mercury autoanalyzer. This method has been described in detail in Choi and Holsen (2009). Choi and Holsen (2009) measured soil Hg fluxes in the same hardwood stand at the HWF; however, they used polycarbonate flux chambers while the current study used Teflon flux chambers. Results from the conifer plot were compared to results from Choi and Holsen (2009) to explore differences in evasion processes between conifer and hardwood stands.

Meteorological and hydrologic variables

Meteorological (precipitation, air temperature, relative humidity, wind speed) and hydrologic measurements (stream discharge) are made continuously at the HWF (http://www.esf.edu/hss/em/index.html). The site for meteorological measurements is immediately adjacent to the location of the hardwood plot for this study, while discharge is measured at Archer Creek in Arbutus Pond watershed. Summary statistics of meteorological variables for study years 2009 and 2010 are presented in Table S1, and stream discharge is presented in Fig. S1 in the supplemental materials. In general, the 2009 growing season was characterized by steady precipitation, cool temperatures, and adequate soil moisture. In 2010, intense rain events were more common but total precipitation quantity was less, while mean temperatures were higher and soil moisture was lower than in 2009. 
Laboratory methods

Before analysis, solid samples were freeze-dried for at least $72 \mathrm{~h}$ to remove moisture. Foliar samples were analyzed for total $\mathrm{Hg}$ using a Milestone DMA-80 (Milestone, Shelton, CT), which utilizes EPA Method 7473 (USEPA 1998). The instrument was calibrated using an apple leaf matrix standard (NIST 1515, $44 \pm$ $4 \mathrm{ng} \mathrm{g}^{-1}$ ), and mussel tissue (NIST 2976, $61 \pm$ $3.6 \mathrm{ng} \mathrm{g}^{-1}$ ) was used as an external check standard.

Soil samples were analyzed for total $\mathrm{Hg}$ using a LECO AMA direct combustion analyzer (LECO Corp.), which also operates based on EPA Method 7473 (USEPA 1998). It was calibrated using a fly-ash standard (NIST 1633b, $143 \pm 2 \mathrm{ng} \mathrm{g}^{-1}$ ) and a marine sediment standard (NRC-Canada MESS-3, $91 \pm 9$ $\mathrm{ng} \mathrm{g}^{-1}$ ) was used as an external check standard.

Aqueous $\mathrm{Hg}$ samples were stored in the dark at $4{ }^{\circ} \mathrm{C}$ until analysis. Samples were treated with bromine monochloride to oxidize $\mathrm{Hg}$ species and then analyzed for total Hg using a Tekran 2600 (Tekran, Inc.) with a cold-vapor atomic fluorescence detector. Samples were analyzed according to EPA Method 1631 (USEPA 2002). Calibration standards were prepared using a certified aqueous $\mathrm{Hg}$ reference stock solution (Ultra Scientific, $10 \mu \mathrm{g} \mathrm{mL}^{-1}$ ) and a certified external $\mathrm{Hg}$ solution (NIST 1641-D). For foliage, soil, and aqueous samples, all calibration verification standards and external check standards were within $10 \%$ of expected concentration.

\section{Deposition calculations and statistics}

Throughfall, litterfall, and total $\mathrm{Hg}$ deposition were calculated for both the hardwood and conifer plot for 2009 and 2010. To simplify calculations, each study year was established at the beginning of the growing season, which was defined as May 15. In this study, references to 2009 indicate the time period from May 15 2009-May 142010 and references to 2010 indicate May 15 2010-May 14 2011. Total Hg deposition is defined as the sum of the throughfall $\mathrm{Hg}$ deposition plus the sum of litter $\mathrm{Hg}$ deposition. Throughfall $\mathrm{Hg}$ deposition was calculated by multiplying throughfall $\mathrm{Hg}$ concentrations $\left(\mathrm{ng} \mathrm{L}^{-1}\right)$ by the throughfall factor $\left(\frac{100 \%-\% \text { interception }}{100 \%}\right)$ and then by measured open precipitation quantity $(\mathrm{cm})$. To account for differences in precipitation type (rain vs. snow) and presence or absence of leaves, study years were also divided by season: spring (March 15-May 15), summer growing season (May 16-October 15), fall (October 16-December 1), and winter (December 2-March 14) and totals from all seasons were summed to calculate annual total $\mathrm{Hg}$ deposition. The summer season was assumed to be the only leaf-on season, and winter was assumed to be the only snow season. For months that throughfall data were collected, monthly deposition was computed based on measured $\mathrm{Hg}$ concentrations. For months that throughfall was not collected, precipitation quantity and $\mathrm{Hg}$ concentrations measured at the MDN station were multiplied by mean throughfall factors $\left(\frac{100 \%-\% \text { interception }}{100 \%}\right)$ and mean enrichment factors ( $\left.\frac{\text { throughfall } \mathrm{Hg} \text { concentration }}{\text { open precipitation } \mathrm{Hg} \text { concentration }}\right)$ from each plot to calculate approximate deposition to each plot.

Litterfall $\mathrm{Hg}$ was calculated based on litterfall mass and foliar $\mathrm{Hg}$ concentrations for each tree species. Total litterfall $\mathrm{Hg}$ deposition to the forest floor was calculated for each plot and for each sampling year. The litterfall mass was calculated by collecting all litter from all litter traps and freeze drying for $72 \mathrm{~h}$ before weighing. Due to plot location, litter could not be collected from traps frequently, and because rain, dew, and snow could increase $\mathrm{Hg}$ concentrations in litter samples (Demers et al. 2007), litter Hg concentrations were determined from regressions of foliar $\mathrm{Hg}$ accumulation as a function of time over the growing season. Foliar $\mathrm{Hg}$ accumulation in hardwoods has been shown to be approximately linear throughout the growing season (Bushey et al. 2008; Rea et al. 2002), so foliar $\mathrm{Hg}$ concentrations were estimated using linear regression. For hardwood species, the growing season was approximated to be 155 days from budbreak to litterfall. White pine typically carries two age classes of needles. As a result, the period of foliar $\mathrm{Hg}$ exposure was assumed to be two years (730 days). The contribution of different age classes to litter from balsam fir and eastern white cedar is not well understood, so an exposure period of three years (1,095 days) was used so that calculated litter $\mathrm{Hg}$ fluxes would represent conservative estimates.

Wet $\mathrm{Hg}$ deposition was assumed to be equivalent to measured deposition at the MDN station. Dry $\mathrm{Hg}$ deposition was calculated by summing throughfall $\mathrm{Hg}$ deposition and litter $\mathrm{Hg}$ deposition and then subtracting wet $\mathrm{Hg}$ deposition from the 
total. Dry $\mathrm{Hg}$ deposition was defined for each plot as $H g_{\text {Throughfall }}-H g_{\text {Precipitation }}+H g_{\text {Litterfall }}$. This approach has been used in previous studies to estimate dry $\mathrm{Hg}$ deposition (Graydon et al. 2008; Driscoll et al. 2007a). For each plot, total $\mathrm{Hg}$ deposition was subdivided into percent wet deposition and percent dry deposition.

One-way ANOVA was used to test differences in foliar $\mathrm{Hg}$ concentrations among species. Student's $t$ test was used to examine differences in throughfall concentrations between the hardwood and conifer plot. For all tests, significance was determined at $\alpha \leq 0.05$. All statistical analyses were performed using IBM-SPSS Statistics 19.0.

\section{Results}

Foliar mercury accumulation and litter fluxes

Mercury concentrations in live foliage increased throughout the growing season for all species in both 2009 and 2010 (Table 1 and Fig. 2). Increases in foliar $\mathrm{Hg}$ were generally linear throughout the growing season for both years, indicating a consistent accumulation of $\mathrm{Hg}$ in foliage. The rates of foliar $\mathrm{Hg}$ accumulation were different for the two growing seasons, but in general patterns showed that $\mathrm{Hg}$ accumulation in deciduous species were over five times greater than conifer species (Table 1). Within the hardwood plot, all canopy species showed similar $\mathrm{Hg}$ uptake rates and patterns in 2010; however, in 2009, American beech had a higher $\mathrm{Hg}$ concentration than both sugar maple and yellow birch by the end of

Table 1 Mean daily $\mathrm{Hg}$ accumulation rate and litter $\mathrm{Hg}$ concentration at time of senescence for tree species for 2009 and 2010

\begin{tabular}{lll}
\hline Species & $\begin{array}{l}\text { Daily } \mathrm{Hg} \\
\text { accumulation } \\
\left(\mathrm{ng} \mathrm{g}^{-1} \mathrm{~d}^{-1}\right)\end{array}$ & $\begin{array}{l}\text { Litter Hg } \\
\text { concentration } \\
\left(\mathrm{ng} \mathrm{g}^{-1}\right)\end{array}$ \\
\hline American beech & $0.235 \pm 0.038$ & $36.5 \pm 5.9$ \\
Sugar maple & $0.207 \pm 0.023$ & $32.0 \pm 3.6$ \\
Yellow birch & $0.207 \pm 0.027$ & $32.1 \pm 4.2$ \\
Balsam fir & $0.031 \pm 0.002$ & $33.6 \pm 2.19$ \\
White pine & $0.040 \pm 0.002$ & $29.4 \pm 1.46$ \\
Eastern white cedar & $0.023 \pm 0.002$ & $24.7 \pm 2.21$ \\
\hline
\end{tabular}

Error measurements represent standard deviation
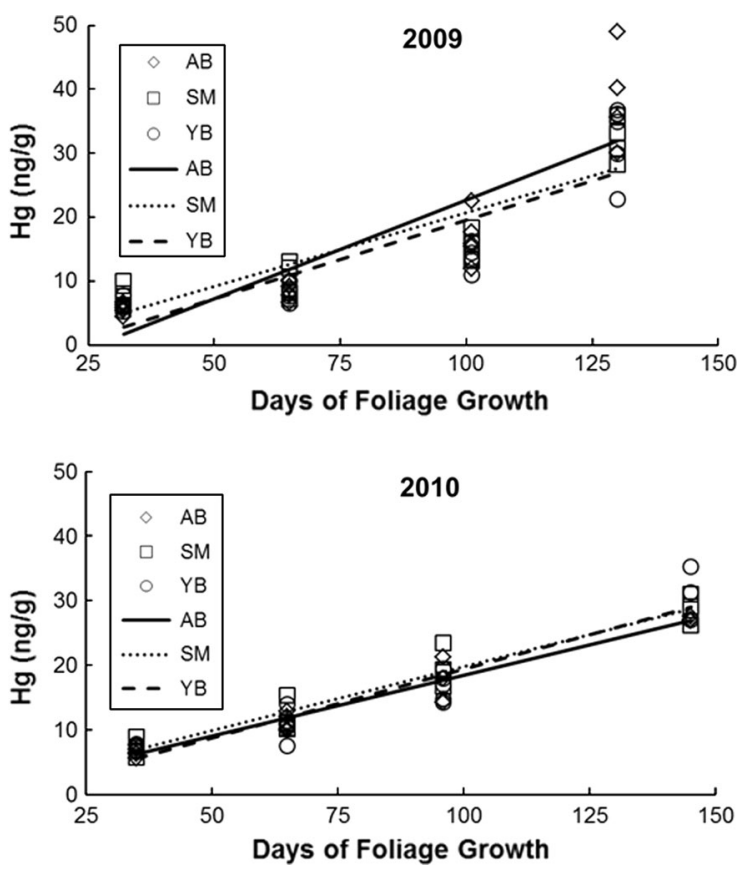

Fig. 2 Mercury concentrations in foliage of hardwood species over the growing seasons of 2009 and 2010. (AB American Beech, SM Sugar Maple, YB Yellow Birch)

the growing season, although this difference was just outside the limits of statistical significance $(p=0.093)$. Mercury accumulation rates in coniferous foliage were greatest in white pine $\left(0.040 \mathrm{ng} \mathrm{g}^{-1}\right.$ day $\left.^{-1}\right)$, followed by balsam fir $\left(0.031 \mathrm{ng} \mathrm{g}^{-1}\right.$ day $\left.^{-1}\right)$ and eastern white cedar $\left(0.023 \mathrm{ng} \mathrm{g}^{-1}\right.$ day $\left.^{-1}\right)$.

Total annual litterfall mass in the hardwood plot was $294 \pm 38 \mathrm{~g} \mathrm{~m}^{-2} \mathrm{yr}^{-1}$ and $230 \pm 16 \mathrm{~g} \mathrm{~m}^{-2} \mathrm{yr}^{-1}$ for 2009 and 2010, respectively. Species contributions to litterfall were approximately $61 \%$ American beech, $23 \%$ sugar maple, and $16 \%$ yellow birch. Annual conifer litterfall flux was greater than hardwood litterfall flux in both sampling years, with averages of $325 \pm 22 \mathrm{~g} \mathrm{~m}^{-2} \mathrm{yr}^{-1}$ and $289 \pm 84 \mathrm{~g} \mathrm{~m}^{-2} \mathrm{yr}^{-1}$ in 2009 and 2010, respectively. Litterfall in the conifer stand was dominated by white pine, which contributed $70 \%$ of total litterfall mass. Mixed hardwoods that were interspersed throughout the conifer plot contributed an additional $22 \%$, while balsam fir and eastern white cedar each contributed approximately $4 \%$ to litter mass.

For the 2009 and 2010 sampling years, total $\mathrm{Hg}$ litterfall deposition was similar between the two plots (Fig. 3). Although litterfall $\mathrm{Hg}$ was approximately equal, litterfall contributed a significantly greater 


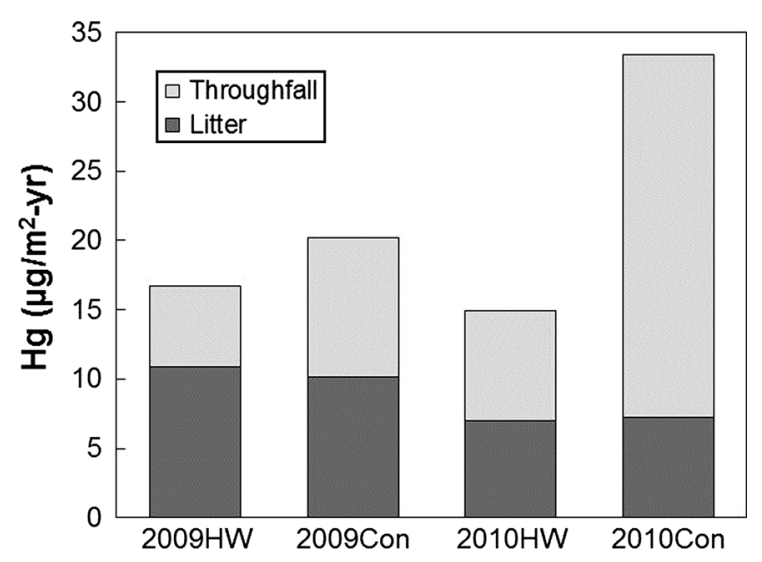

Fig. 3 Contributions of throughfall and litterfall to total $\mathrm{Hg}$ deposition at hardwood (HW) and coniferous (Con) plots at the Huntington Wildlife Forest for 2009 and 2010

percentage of total $\mathrm{Hg}$ deposition in the hardwood plot. Litter accounted for 65 and $47 \%$ of total $\mathrm{Hg}$ deposition in 2009 and 2010 in the hardwood plot compared to 50 and $21 \%$ in the conifer plot.

Precipitation, snow, and throughfall mercury

Total $\mathrm{Hg}$ concentrations in throughfall were greater than in open precipitation samples in both 2009 and 2010 (Fig. 4). Volume-weighted average Hg concentrations for throughfall were 2.0 and 3.7 times higher than precipitation in the conifer plot and 1.29 and 1.20 times higher in the hardwood plot in 2009 and 2010, respectively. When comparing throughfall concentrations between the conifer and hardwood plots, differences were statistically significant for every sampling period of both sample years.

Snow throughfall $\mathrm{Hg}$ concentrations were higher compared to open snowfall, but the magnitude of enrichment was variable. When compared to snow samples from the open clearing, snow throughfall $\mathrm{Hg}$ concentrations were enriched by $50 \%(1.49$ vs. $2.24 \mathrm{ng}$ $\left.\mathrm{L}^{-1}\right)$ and $128 \%$ (0.7 vs. $\left.1.6 \mathrm{ng} \mathrm{L}^{-1}\right)$. Interception of snow was consistent for both sampling events, as snowfall volumes beneath the canopy were measured at 78 and $74 \%$ of volumes from the clearing.

Wet deposition at the MDN station was 6.0 and $7.5 \mathrm{\mu g} \mathrm{m}^{-2} \mathrm{yr}^{-1}$ for 2009 and 2010, respectively. Throughfall deposition within the hardwood plot was nearly identical to wet deposition, with calculated $\mathrm{Hg}$ fluxes of 5.9 and $7.9 \mu \mathrm{g} \mathrm{m}^{-2} \mathrm{yr}^{-1}$ in 2009 and 2010 , respectively. Throughfall $\mathrm{Hg}$ within the conifer plot

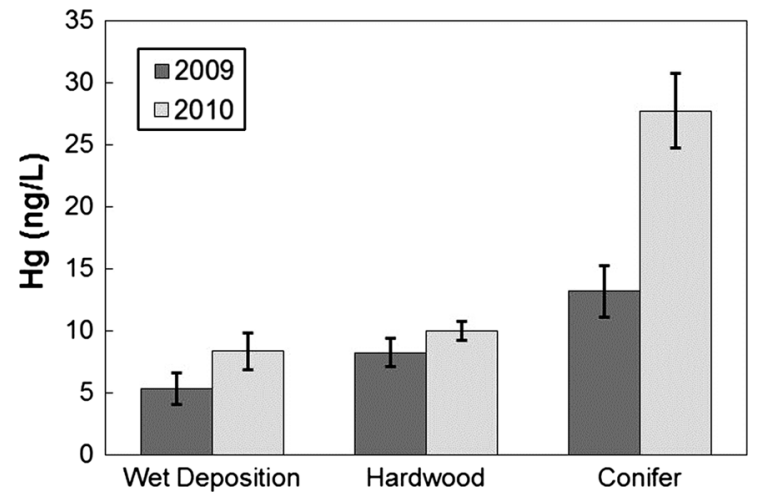

Fig. 4 Mean $\mathrm{Hg}$ concentrations in wet deposition, hardwood throughfall, and coniferous throughfall from 2009 and 2010. Error bars represent standard errors

was considerably greater than both wet deposition and throughfall deposition in the hardwood plot. The calculated throughfall $\mathrm{Hg}$ flux of $10.1 \mathrm{\mu g} \mathrm{m}^{-2} \mathrm{yr}^{-1}$ in the conifer plot in 2009 was about $72 \%$ higher than the calculated throughfall $\mathrm{Hg}$ deposition to the hardwood plot. The difference was even greater in 2010, as the conifer throughfall total of $26.2 \mu \mathrm{g} \mathrm{m}^{-2} \mathrm{yr}^{-1}$ of wet deposition was over three times greater than throughfall $\mathrm{Hg}$ deposition in the hardwood plot.

\section{Mercury in soil}

Total Hg concentrations were lower in the coniferous plot than in comparable horizons in the hardwood plot, although differences were not significant (Table 2). Both plots showed a pattern of decreasing total $\mathrm{Hg}$ concentrations with increasing depth from surface organic layers downward through the mineral soil. Total Hg pools in the top three horizons (Oa, Bh, Bs1) were similar between the plots, with a total of $13.9 \mathrm{mg} \mathrm{m}^{-2}$ in the conifer plot and $12.5 \mathrm{mg} \mathrm{m}^{-2}$ in the hardwood plot (Table 2). Mercury pools in the $\mathrm{Oa}$ horizon were approximately $50 \%$ greater in the hardwood plot than the conifer plot (3.7 vs. $2.9 \mathrm{mg} \mathrm{m}^{-2}$ ), but Bh horizon pools in the conifer plot were approximately double hardwood pools (5.5 vs. $2.7 \mathrm{mg} \mathrm{m}^{-2}$ ). Overall, hardwood soils had greater pools of $\mathrm{Hg}$ (40.6 vs. $33.8 \mathrm{mg} \mathrm{m}^{-2}$ ) due to higher concentrations of $\mathrm{Hg}$ in the $\mathrm{Bs} 3$ and $\mathrm{C}$ horizons, which despite having the lowest concentrations of any horizons, contribute substantially to the overall pool of soil $\mathrm{Hg}$. Note that error estimates were not calculated for soil pools, but because of high 
Table 2 Soil $\mathrm{Hg}$ concentrations and pools for different horizons

\begin{tabular}{|c|c|c|c|c|c|c|c|c|}
\hline \multirow[t]{2}{*}{ Horizon } & \multicolumn{4}{|l|}{ Hardwood } & \multicolumn{4}{|l|}{ Conifer } \\
\hline & $\begin{array}{l}\mathrm{Hg} \\
\left(\mathrm{ng} \mathrm{g}^{-1}\right)\end{array}$ & $\begin{array}{l}\text { Bulk Density } \\
\left(\mathrm{g} \mathrm{cm}^{-3}\right)\end{array}$ & $\begin{array}{l}\text { Thickness } \\
(\mathrm{cm})\end{array}$ & $\begin{array}{l}\text { Pool } \\
\left(\mathrm{mg} \mathrm{m}^{-2}\right)\end{array}$ & $\begin{array}{l}\mathrm{Hg} \\
\left(\mathrm{ng} \mathrm{g}^{-1}\right)\end{array}$ & $\begin{array}{l}\text { Bulk Density } \\
\left(\mathrm{g} \mathrm{cm}^{-3}\right)\end{array}$ & $\begin{array}{l}\text { Thickness } \\
(\mathrm{cm})\end{array}$ & $\begin{array}{l}\text { Pool } \\
\left(\mathrm{mg} \mathrm{m}^{-2}\right)\end{array}$ \\
\hline $\mathrm{Oa}$ & $148 \pm 8$ & 0.28 & 9 & 3.7 & $84 \pm 20$ & 0.39 & 8 & 2.8 \\
\hline $\mathrm{Bh}$ & $70 \pm 5$ & 0.54 & 7 & 2.7 & $76 \pm 15$ & 0.73 & 10 & 5.5 \\
\hline Bs1 & $85 \pm 8$ & 0.60 & 12 & 6.1 & $59 \pm 7$ & 0.80 & 12 & 5.6 \\
\hline Bs2-C & $56 \pm 15$ & 0.75 & 72 & 28.1 & $34 \pm 10$ & 0.83 & 69 & 19.9 \\
\hline Total & - & - & - & 40.6 & - & - & - & 33.8 \\
\hline
\end{tabular}

Soil profiles were calculated on an assumed total depth of $1 \mathrm{~m}$. Bulk density values are estimated from measurements of Bedison (2009). Error measurements are standard deviation

Table 3 Seasonal and annual $\mathrm{Hg}^{0}$ evasion fluxes from the soil surface in the hardwood and conifer plots

\begin{tabular}{|c|c|c|c|c|c|c|c|c|}
\hline \multirow[t]{2}{*}{ Season } & \multicolumn{4}{|c|}{ Hardwood } & \multicolumn{4}{|l|}{ Conifer } \\
\hline & $\begin{array}{l}\text { Spring } \\
\left(\mathrm{ng} \mathrm{\textrm {m } ^ { - 2 }}\right. \\
\left.\mathrm{h}^{-1}\right)\end{array}$ & $\begin{array}{l}\text { Summer } \\
\left(\mathrm{ng} \mathrm{m} \mathrm{m}^{-2}\right. \\
\left.\mathrm{h}^{-1}\right)\end{array}$ & $\begin{array}{l}\text { Fall } \\
\left(\mathrm{ng} \mathrm{m} \mathrm{m}^{-2}\right. \\
\left.\mathrm{h}^{-1}\right)\end{array}$ & $\begin{array}{l}\text { Annual } \\
\left(\mu \mathrm{g} \mathrm{m}^{-2}\right. \\
\left.\mathrm{yr}^{-1}\right)\end{array}$ & $\begin{array}{l}\text { Spring } \\
\left(\mathrm{ng} \mathrm{m}^{-2}\right. \\
\left.\mathrm{h}^{-1}\right)\end{array}$ & $\begin{array}{l}\text { Summer } \\
\left(\mathrm{ng} \mathrm{m}^{-2}\right. \\
\left.\mathrm{h}^{-1}\right)\end{array}$ & $\begin{array}{l}\text { Fall } \\
\left(\mathrm{ng} \mathrm{\textrm {m } ^ { - 2 }}\right. \\
\left.\mathrm{h}^{-1}\right)\end{array}$ & $\begin{array}{l}\text { Annual } \\
\left(\mu \mathrm{g} \mathrm{m}{ }^{-2}\right. \\
\left.\mathrm{yr}^{-1}\right)\end{array}$ \\
\hline Mean & 1.55 & 1.46 & 0.82 & 7.0 & -0.04 & 0.39 & -0.68 & -1.0 \\
\hline Maximum & 27.10 & 5.26 & 4.12 & - & 4.20 & 6.65 & 3.63 & - \\
\hline Minimum & -2.49 & -1.34 & -1.92 & - & -2.09 & -3.20 & -2.44 & - \\
\hline
\end{tabular}

Hardwood fluxes were determined by Choi and Holsen (2009)

variability in soil $\mathrm{Hg}$ concentrations, horizon thickness, and bulk density, calculated soil pools from this study have a high degree of uncertainty.

\section{Soil Hg evasion}

Gaseous emissions of elemental mercury $\left(\mathrm{Hg}^{0}\right)$ from the soil surface to the atmosphere were monitored during fall 2009 and spring and summer 2010, and these results were compared to rates at the hardwood plot at the HWF described in Choi et al. (2009) (Table 3). Soil evasion was considerably lower in the conifer plot than the hardwood plot, with summer being the only season that $\mathrm{Hg}^{0}$ was released from the soil. $\mathrm{Hg}^{0}$ emission fluxes were positively correlated with air temperature and solar radiation in both plots, but were negatively correlated with relative humidity for most sampling periods (data not shown).

Total net $\mathrm{Hg}$ fluxes

Based on results from 2009 to 2010, mean total $\mathrm{Hg}$ deposition into the hardwood plot was
$15.9 \mu \mathrm{g} \mathrm{m}^{-2} \mathrm{yr}^{-1}$, while mean total deposition to the conifer plot was $26.8 \mu \mathrm{g} \mathrm{m}^{-2} \mathrm{yr}^{-1}$ (Fig. 5). This difference was largely due to greater throughfall inputs in the conifer plot in 2010. Dry deposition was the dominant pathway of $\mathrm{Hg}$ deposition to the conifer plot in both 2009 and 2010 (71 and $78 \%$ of total). For the hardwood plot, dry deposition was the dominant $\mathrm{Hg}$ deposition pathway in 2009 (69\%), but wet and dry deposition were essentially equal in 2010 (51\% wet, $49 \%$ dry). For the leaf-on period only (May-October), dry deposition was the dominant $\mathrm{Hg}$ pathway to the hardwood plot, accounting for $79 \%$ of total deposition in 2009 and $68 \%$ in 2010.

When combining deposition fluxes with soil evasion, the difference in net $\mathrm{Hg}$ deposition between forest stands becomes even more evident (Fig. 5). The hardwood plot released an estimated $7 \mu \mathrm{g} \mathrm{m}^{-2} \mathrm{yr}^{-1}$ of $\mathrm{Hg}^{0}$ through soil evasion, resulting in net total $\mathrm{Hg}$ deposition for the plot of $8.9 \mu \mathrm{g} \mathrm{m}^{-2} \mathrm{yr}^{-1}$. In contrast, the conifer plot had deposition of $\mathrm{Hg}^{0}$ rather than evasion, resulting in an estimated net total $\mathrm{Hg}$ deposition of $27.8 \mu \mathrm{g} \mathrm{m}^{-2} \mathrm{yr}^{-1}$. 
Fig. 5 Conceptual illustration of $\mathrm{Hg}$ inputs $\left(\mu \mathrm{g} \mathrm{m}^{-2} \mathrm{yr}^{-1}\right)$, evasion $\left(\mu \mathrm{g} \mathrm{m}^{-2} \mathrm{yr}^{-1}\right)$, and soil $\mathrm{Hg}$ pools $\left(\mathrm{mg} \mathrm{m}^{-2}\right)$ in hardwood stand and conifer stand at the Huntington Wildlife Forest

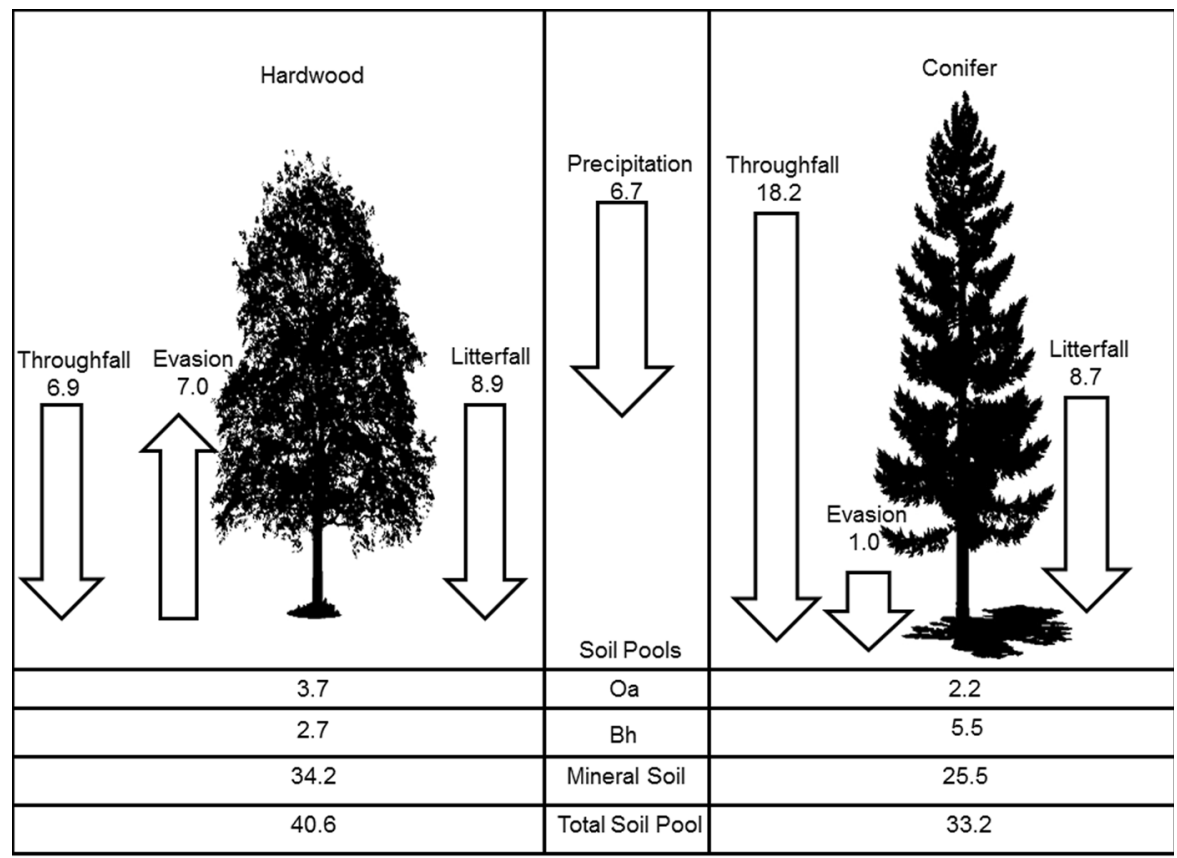

\section{Discussion}

Foliar mercury and litter dynamics

Previous studies have documented that the majority of $\mathrm{Hg}$ that accumulates in foliage is of atmospheric origin (Bushey et al. 2008; Ericksen et al. 2003; Rea et al. 2001; Rasmussen 1995), although a fraction could be due to recycled $\mathrm{Hg}$ from recent soil $\mathrm{Hg}$ evasion (Bushey et al. 2008). Foliar Hg concentrations and uptake rates varied among tree species, and the most substantial differences were evident between hardwood and conifer species. Daily $\mathrm{Hg}$ accumulation rates in hardwood species were approximately five to seven times greater than conifer species. This finding is in line with other studies that have measured lower $\mathrm{Hg}$ uptake in conifer species than hardwood species (Hanson et al. 1995). Conifers generally fix carbon at a lower rate than deciduous species (Catovsky et al. 2002). Foliar $\mathrm{Hg}$ uptake is related to the density of stomata on the leaf surface (Laacouri et al. 2013), and although values are highly variable among species, average stomatal conductance is also generally lower in conifers (Medlyn et al. 2001). These characteristics imply that at a uniform concentration of atmospheric $\mathrm{Hg}$, hardwoods would cycle more $\mathrm{Hg}^{0}$ through leaves than conifers, effectively increasing their $\mathrm{Hg}$ exposure. This physiological difference could account for the large differences in $\mathrm{Hg}$ uptake between hardwood and conifer foliage.

Throughfall concentrations and fluxes

Increased concentrations of $\mathrm{Hg}$ in hardwood throughfall compared to open precipitation have been documented in many studies (e.g., Choi et al. 2008; Rea et al. 2001; Rea et al. 1996). However, few have examined throughfall enrichment by conifers (Witt et al. 2009; St. Louis et al. 2001; Kolka et al. 1999). In this study, throughfall in the conifer plot contained significantly higher $\mathrm{Hg}$ concentrations than both wet deposition and throughfall from the hardwood plot. Kolka et al. (1999) also measured throughfall $\mathrm{Hg}$ in conifers and found that coniferous throughfall deposition was approximately double open precipitation deposition. This enrichment compares well with our measurements in 2009, but the difference was even more evident in 2010 as conifer throughfall deposition was 3.7 times greater than wet deposition. Forest canopies decrease the volume of precipitation that reaches the forest floor. As a result, throughfall $\mathrm{Hg}$ concentration enrichment is partially offset by water quantity losses due to interception. Deposition calculations from our study suggest that canopy $\mathrm{Hg}$ 
enrichment and interception water losses essentially offset one another in the hardwood stand, which is consistent with previous net throughfall estimates from Huntington Forest (Choi et al. 2008). Despite conifer forests having a slightly higher interception rate than hardwoods, there was a much greater canopy enrichment effect resulting in significantly greater $\mathrm{Hg}$ throughfall flux compared to wet deposition.

Even though hardwood foliage apparently takes up greater amounts of atmospheric $\mathrm{Hg}^{0}$, evidence indicates that conifers are more effective at removing $\mathrm{Hg}^{2+}$ from the atmosphere than deciduous canopies (Kolka et al. 1999). This $\mathrm{Hg}^{2+}$ is not immobilized by the canopy and is washed from needles during precipitation events. Leached $\mathrm{Hg}^{2+}$ may be complexed with DOC exuded from needle surfaces, as there is a strong correlation between DOC and $\mathrm{Hg}$ concentrations in throughfall samples (Kolka et al. 1999). $\mathrm{Hg}^{2+}$ is estimated to make up only about $3 \%$ of total gaseous $\mathrm{Hg}$ concentrations in Upstate New York (Yu et al. 2013a; Han et al. 2004), but it is thought to contribute substantially to dry $\mathrm{Hg}$ deposition (Lindberg and Stratton 1998; Driscoll et al. 2007b). $\mathrm{Hg}^{2+}$ and DOC are readily leached from needle surfaces. The source of DOC in throughfall samples is likely to be from the canopy because DOC concentrations in throughfall are elevated over bulk deposition measurements for northeastern U.S. forests (Likens et al. 1983).

\section{Accumulation of mercury in soil}

Inputs of $\mathrm{Hg}$ from throughfall and litterfall are eventually deposited to the forest floor and potentially incorporated into soil layers. Both stands showed enrichment of $\mathrm{Hg}$ from the litter (Oi/Oe) to the organic humus (Oa) layer, which is likely due to a combination of mass loss due to decomposition, soil surface $\mathrm{Hg}$ evasion, and sorption of $\mathrm{Hg}$ inputs from throughfall in the Oa horizon (Demers et al. 2007). Coincident with an increase in $\mathrm{Hg}$, a decrease in the organic carbon content from Oi/Oe to the Oa horizon was observed. Organic carbon is not sufficient to explain the increase in $\mathrm{Hg}$ from the Oi/Oe to the Oa layer. The balance of the increase is likely from $\mathrm{Hg}$ inputs due to throughfall percolation through the soil profile and subsequent adsorption of $\mathrm{Hg}$. Mass-balance of $\mathrm{Hg}$ due to loss of litter mass and inputs from throughfall has been outlined in detail in Demers et al. (2007), and while throughfall $\mathrm{Hg}$ could sufficiently account for soil $\mathrm{Hg}$ enrichment within conifer plots, it was an insufficient source to totally account for $\mathrm{Hg}$ increases in hardwood soils (Demers et al. 2007).

Soil $\mathrm{Hg}$ pools measured at HWF are somewhat greater than mean values estimated for the Adirondacks and the Northeast in a regional survey ( $\mathrm{Yu}$ et al. 2013b). The forest stands used in this study are on similar soils with common characteristics, and as a result, it would be expected that increased $\mathrm{Hg}$ fluxes to the conifer plot would result in greater accumulation of $\mathrm{Hg}$ in the soil profile than in the hardwood plot. However, soil $\mathrm{Hg}$ concentrations were not significantly different between the hardwood and conifer plot even though the forest floor of the conifer plot received substantially higher $\mathrm{Hg}$ loading. Calculated $\mathrm{Hg}$ pools within upper soil layers (Oa, Bh, and Bs1 layers) were also similar between the two plots (Table 2). A similar pattern for hardwood and conifer plots was reported by Demers et al. (2007), and they hypothesized that this discrepancy may be offset by greater rates of $\mathrm{Hg}^{0}$ evasion from soils under conifer stands. However, very low rates of $\mathrm{Hg}^{0}$ evasion were observed in the conifer stand at the HWF. Lower soil $\mathrm{Hg}^{0}$ emissions are likely partially due to the dense, year-round canopy of the conifer plot, since solar radiation and increased temperatures stimulate evasion of $\mathrm{Hg}$ from the soil surface (Choi and Holsen 2009). This discrepancy of greater $\mathrm{Hg}$ inputs but lower soil $\mathrm{Hg}$ storage and evasion than the hardwood stand suggests there is an additional loss mechanism of $\mathrm{Hg}$ from the conifer stand. Some of this loss might be due to uptake of $\mathrm{Hg}$ by woody structures in trees. In western North America, some conifer species have been shown to store significantly more $\mathrm{Hg}$ in roots and stems than hardwood species (Obrist et al. 2012). If a similar pattern occurs for white pine and northern hardwood species, this mechanism could account for a portion of the discrepancy in $\mathrm{Hg}$ mass balance between the stands.

Another potential pathway is enhanced drainage losses through soil solutions. Drainage is generally considered to be a relatively minor loss mechanism of $\mathrm{Hg}$ in forest stands (Demers et al. 2007). The concentrations of $\mathrm{Hg}$ and DOC in soil solutions are well correlated, and soil solutions from conifer stands have been shown to have significantly higher concentrations of DOC than hardwood stands (Kalbitz et al. 2000). Mercury concentrations in soil solutions are 
rare in the literature (but see $\AA$ kerblom et al. 2008), but DOC concentrations in soil solutions are measured more frequently in biogeochemical studies. One of the most detailed studies of soil solution chemistry from forests of the Northeast has been conducted at the Hubbard Brook Experimental Forest (HBEF) in New Hampshire. Analysis over a 12-year period at the HBEF found that DOC concentrations were substantially higher in soil solutions ( $\mathrm{Oa}, \mathrm{Bh}$ and Bs horizons) and streamwater from a coniferous drainage basin than in a hardwood drainage basin (Dittman et al. 2007). This literature suggests that $\mathrm{Hg}$ losses by drainage could be greater in conifer stands than in hardwoods. During high-flow rain events or snow-melt, drainage fluxes are amplified further. Concentrations of DOC and $\mathrm{Hg}$ increase in streams and rivers as soil solutions rapidly drain from soil profiles (Demers et al. 2010, Schuster et al. 2008). Aquatic ecosystems that drain watersheds largely composed of coniferous forest species may be at a higher risk of $\mathrm{Hg}$ contamination than aquatic ecosystems in largely hardwood forested watersheds. Previous research has shown that a large portion of DOC in Adirondack lakes is derived from terrestrial sources (Canham et al. 2004). In addition, a landscape level study found a correlation between percent coniferous land cover and watershed export of DOC (Aitkenhead-Peterson et al. 2007), while others found elevated $\mathrm{Hg}$ concentrations in ecoregions that contain high percentages of coniferous land cover (Drenner et al. 2013; Drenner et al. 2011). Coniferous land cover could potentially be an important variable in $\mathrm{Hg}$ availability to a watershed, and future landscape level studies may benefit from exploring this relationship.

Contributions of wet and dry deposition to total $\mathrm{Hg}$ deposition were similar for this study and others in similar forests. A regional model of $\mathrm{Hg}$ deposition projected approximately $67 \%$ dry deposition and $33 \%$ wet deposition in the Adirondack region (Miller et al. 2005). St. Louis et al. (2001) found that dry deposition was the most significant pathway of $\mathrm{Hg}$ inputs despite low atmospheric $\mathrm{Hg}^{2+}$ concentrations in the Experimental Lakes Area of Canada. Litterfall accounted for the majority of dry $\mathrm{Hg}$ deposition and is an important source of $\mathrm{Hg}$ to the forest floor, especially in hardwood stands. Dry deposition during the leaf-on period accounted for an even greater percentage of total $\mathrm{Hg}$ deposition when compared to the entire year, suggesting that dry $\mathrm{Hg}$ deposition and litter $\mathrm{Hg}$ deposition could be greater at lower latitudes due to prolonged growing season and leaf-on period.

A simple comparison of $\mathrm{Hg}$ deposition via throughfall and litterfall relative to total deposition provides an approximate estimate of relative contributions of reduced $\left(\mathrm{Hg}^{0}\right)$ and oxidized $\left(\mathrm{Hg}^{2+}\right) \mathrm{Hg}$ to ecosystem deposition. Throughfall is thought to be largely $\mathrm{Hg}^{2+}$ inputs (Rea et al. 2001), and $68 \%$ of $\mathrm{Hg}$ in the conifer plot in 2009-2010 was deposited via throughfall, indicating the majority of $\mathrm{Hg}$ was deposited as $\mathrm{Hg}^{2+}$. In contrast, only $43 \%$ of $\mathrm{Hg}$ deposition in the hardwood plot was due to throughfall, while the remainder was due to litterfall. Litter is assumed to contribute mostly $\mathrm{Hg}^{0}$, suggesting that the majority of deposition $(57 \%)$ in the hardwood plot was likely deposited as $\mathrm{Hg}^{0}$ through litterfall.

\section{Meteorological variation and climate influence}

Considerable year-to-year variability in foliar and throughfall $\mathrm{Hg}$ concentrations was evident in our study between 2009 and 2010. Foliar $\mathrm{Hg}$ concentrations from the HWF in 2004 and 2005 (Bushey et al. 2008) compared well to 2009 values, but 2010 concentrations were appreciably lower. This response might be explained by differences in meteorology between the 2009 and 2010 growing seasons. Precipitation totals were lower during the 2010 growing season than in 2009, and higher air temperatures in 2010 likely led to higher moisture deficits. In addition, the Adirondack region experienced a period of abnormally dry conditions in the months of April and May 2010 (U.S. Drought Monitor, droughtmonitor.unl.edu). Stream discharges are closely related to soil moisture (Groffman et al. 2012), and stream discharge patterns indicate that 2009 was characterized by more even precipitation and steadier discharges, while 2010 had high-intensity rain events followed by prolonged periods of dryness and low discharge, likely reflecting lower soil moisture (Fig. S1). Pre-growing season dryness coupled with lower precipitation totals and higher air temperatures during the 2010 growing season likely led to low soil moisture and water stress in the forest plots. Both conifers and hardwoods show decreases in transpiration and stomatal uptake in response to moisture deficits (Leuzinger et al. 2005; Irvine et al. 1998; Maier and Teskey 1992). Foliar uptake of $\mathrm{Hg}$ is likely coupled with stomatal gas exchange, so decreases in gas uptake due to drought 
stress in 2010 likely contributed to the lower $\mathrm{Hg}$ accumulation in foliage.

Changes in foliar uptake in response to variation in meteorological conditions may have important implications for changes in $\mathrm{Hg}$ deposition and cycling due to $\mathrm{CO}_{2}$-induced climate change. Climate change is expected to increase global temperatures and alter weather patterns. Increased $\mathrm{CO}_{2}$ could potentially increase soil storage capacity of $\mathrm{Hg}$ through increases in soil organic matter (Natali et al. 2008). In the northeastern United States, climate change is also expected to increase precipitation quantity and variability, cause lower snowpack accumulation and earlier snowmelt, increase transpiration, and decrease soil moisture during the growing season (Hayhoe et al. 2008; Plummer et al. 2006). If such a decrease in soil moisture was sufficient to increase the occurrence of drought stress, the result could be an overall decrease in $\mathrm{Hg}$ litter deposition due to decreased foliar $\mathrm{Hg}$ uptake and subsequent litterfall deposition. This change would be particularly important in hardwood forests, where litter deposition is the primary input of $\mathrm{Hg}$ into the forest floor. $\mathrm{Hg}$ litter deposition in the hardwood plot in 2010 was about $30 \%$ less than in 2009 due to decreases in both litter mass and foliar $\mathrm{Hg}$ concentrations, indicating that climatic variability could have a demonstrable impact on $\mathrm{Hg}$ litterfall deposition.

The conifer plot also exhibited a decrease in litterfall $\mathrm{Hg}$ in 2010, but despite this decrease, dry $\mathrm{Hg}$ deposition in the conifer plot increased over $60 \%$ in 2010 versus 2009 due to higher $\mathrm{Hg}$ concentrations in throughfall. Concentrations of $\mathrm{Hg}$ in throughfall have shown positive correlation with the duration of dry weather preceding a rain event (Choi et al. 2008; Rea et al. 2002), and the average period between rain events in 2010 was longer than 2009 (68 rain free growing-season days in 2010, 54 in 2009). Warm temperatures and dry weather also increase atmospheric $\mathrm{Hg}^{2+}$ concentrations (Han et al. 2004). Yu et al. (2013a) measured ambient air concentrations of reactive gaseous $\mathrm{Hg}(\mathrm{RGM})$ and particulate $\mathrm{Hg}\left(\mathrm{Hg}_{\mathrm{p}}\right)$, the main components of $\mathrm{Hg}^{2+}$, at the HWF in 2009 and 2010. Concentrations of $\mathrm{Hg}^{2+}$ were significantly higher in 2010 than in 2009 (mean $\mathrm{RGM}+\mathrm{Hg}_{\mathrm{p}}$ was 1.7 and $6.0 \mathrm{pg} \mathrm{m}^{-3}$ for 2009 and 2010, respectively) (Yu et al. 2013a). Conifer needles with high leaf area index are more efficient at collecting $\mathrm{Hg}^{2+}$ from the atmosphere than hardwood leaves. The implications of this pattern are that an increased interval between precipitation events and higher temperatures would likely increase $\mathrm{Hg}$ deposition to conifer forests by increasing $\mathrm{Hg}^{2+}$ adsorption and wash-off, leading to increased throughfall $\mathrm{Hg}$ concentrations and deposition. Note that this variation in meteorological conditions, while apparently decreasing $\mathrm{Hg}$ inputs to the hardwood stand, increased $\mathrm{Hg}$ inputs to the conifer stand. This pattern suggests that there could be a shift in not only total $\mathrm{Hg}$ inputs, but also pathways of these inputs to forests under changing climatic conditions, and watersheds composed largely of coniferous forests could receive greater $\mathrm{Hg}$ loading under the expected future climate conditions.

\section{Conclusions}

Overall, this work demonstrates that both hardwood and coniferous forests receive substantial inputs of $\mathrm{Hg}$ through both litter and throughfall, with litter being the dominant flux in hardwood forests and throughfall being the dominant flux in conifer forests. Despite significantly greater $\mathrm{Hg}$ inputs to the forest floor and lower evasion losses in conifer stands, the concentrations and pools of $\mathrm{Hg}$ in the soil of the conifer stand were not significantly different than hardwood stands. This discrepancy suggests there is a loss mechanism in coniferous forests that has not been adequately quantified. These losses may be explained by leaching of soil $\mathrm{Hg}$ in conjunction with DOC in soil solutions. Dissolved organic carbon has been shown to leach more readily from coniferous stands than from hardwood stands, so aquatic ecosystems located in watersheds that are forested with a high percentage of conifers may be at an increased risk of $\mathrm{Hg}$ contamination compared to aquatic ecosystems in deciduous forested watersheds. Previous papers have referred to forest soils as a net sink of atmospheric $\mathrm{Hg}$ (Graydon et al. 2008; Kolka et al. 1999), but this sink for atmospheric $\mathrm{Hg}$ could potentially be a significant source of $\mathrm{Hg}$ to surface waters. Moreover, there was significant year-to-year variation in the magnitude and pathways of $\mathrm{Hg}$ deposition between stands, seemingly due to differences in precipitation and temperatures. Predicted changes in climatic conditions in the northeastern United States could shift $\mathrm{Hg}$ deposition pathways by decreasing litterfall $\mathrm{Hg}$ deposition and increasing throughfall $\mathrm{Hg}$ deposition in forested ecosystems. 
Acknowledgments This work was supported by the New York State Energy Research and Development Authority and a Syracuse University fellowship to BB. We appreciate the help of Pat McHale and Myron Mitchell in providing hydrologic data.

Open Access This article is distributed under the terms of the Creative Commons Attribution License which permits any use, distribution, and reproduction in any medium, provided the original author(s) and the source are credited.

\section{References}

Aitkenhead-Peterson JA, Smart RP, Aitkenhead MJ et al (2007) Spatial and temporal variation of dissolved organic carbon export from gauged and ungauged watersheds of dee valley, Scotland: effect of land cover and C: N. Water Resour Res 43:W05442

Åkerblom S, Meili M, Bringmark L et al (2008) Partitioning of $\mathrm{Hg}$ between solid and dissolved organic matter in the humus layer of boreal forests. Water Air Soil Pollut 189:239-252. doi:10.1007/s11270-007-9571-1

Bedison JE (2009) Decadal-scale comparisons of vegetation and soil properties in forests of the Adirondack Mountains, NY. Dissertations available from ProQuest 1-445

Bushey JT, Nallana AG, Montesdeoca MR, Driscoll CT (2008) Mercury dynamics of a northern hardwood canopy. Atmos Environ 42:6905-6914. doi:10.1016/j.atmosenv.2008.05. 043

Canham CD, Pace ML, Papaik MJ et al (2004) A spatially explicit watershed-scale analysis of dissolved organic carbon in adirondack lakes. Ecol Appl 14:839-854. doi:10. 2307/4493584

Catovsky S, Holbrook NM, Bazzaz FA (2002) Coupling wholetree transpiration and canopy photosynthesis in coniferous and broad-leaved tree species. Can J For Res 32:295-309. doi:10.1139/x01-199

Choi H-D, Holsen TM (2009) Gaseous mercury fluxes from the forest floor of the Adirondacks. Environ Pollut 157:592-600. doi:10.1016/j.envpol.2008.08.020

Choi H-D, Sharac TJ, Holsen TM (2008) Mercury deposition in the Adirondacks: a comparison between precipitation and throughfall. Atmos Environ 42:1818-1827. doi:10.1016/j. atmosenv.2007.11.036

Demers JD, Driscoll CT, Fahey TJ, Yavitt JB (2007) Mercury cycling in litter and soil in different forest types in the Adirondack region, New York, USA. Ecol Appl 17:1341-1351. doi:10.2307/40062037

Demers JD, Driscoll CT, Shanley JB (2010) Mercury mobilization and episodic stream acidification during snowmelt: role of hydrologic flow paths, source areas, and supply of dissolved organic carbon. Water Resour Res 46. doi: 10. 1029/2008WR007021

Dittman JA, Driscoll CT, Groffman PM, Fahey TJ (2007) Dynamics of nitrogen and dissolved organic carbon at the hubbard brook experimental forest. Ecology 88:1153-1166. doi:10.1890/06-0834
Drenner RW, Chumchal MM, Wente SP et al (2011) Landscapelevel patterns of mercury contamination of fish in North Texas, USA. Environ Toxicol Chem 30:2041-2045. doi:10.1002/etc.589

Drenner RW, Chumchal MM, Jones CM et al (2013) Effects of mercury deposition and coniferous forests on the mercury contamination of fish in the South Central United States. Environ Sci Technol 47:1274-1279. doi:10.1021/ es303734n

Drevnick PE, Engstrom DR, Driscoll CT et al (2012) Spatial and temporal patterns of mercury accumulation in lacustrine sediments across the Laurentian Great Lakes region. Environ Pollut 161:252-260. doi:10.1016/j.envpol.2011. 05.025

Driscoll CT, HanY-J Chen CY et al (2007a) Mercury contamination in forest and freshwater ecosystems in the Northeastern United States. Bioscience 57:17-28. doi:10.1641/ B570106

Driscoll CT, Abbott M, Bullock R et al (2007b) Airsheds and watersheds. In: Harris R et al (eds) Ecosystem responses to mercury contamination: indicators of change. CRC Press, Boca Raton, pp 13-35

Driscoll CT, Mason RP, Chan HM et al (2013) Mercury as a Global Pollutant: sources, Pathways, and Effects. Environ Sci Technol 47:4967-4983. doi:10.1021/es305071v

Ericksen JA, Gustin MS, Schorran DE et al (2003) Accumulation of atmospheric mercury in forest foliage. Atmos Environ 37:1613-1622. doi:10.1016/S1352-2310(03) 00008-6

Fitzgerald WF, Engstrom DR, Mason RP, Nater EA (1998) The case for atmospheric mercury contamination in remote areas. Environ Sci Technol 32:1-7. doi:10.1021/ es970284w

Graydon JA, St. Louis VL, Hintelmann H et al (2008) Longterm wet and dry deposition of total and methyl mercury in the remote boreal ecoregion of Canada. Environ Sci Technol 42:8345-8351. doi:10.1021/es801056j

Groffman PM, Rustad LE, Templer PH et al (2012) Long-term integrated studies show complex and surprising effects of climate change in the Northern Hardwood Forest. Bioscience 62:1056-1066. doi:10.1525/bio.2012.62.12.7

Han Y-J, Holsen TM, Lai S-O et al (2004) Atmospheric gaseous mercury concentrations in New York State: relationships with meteorological data and other pollutants. Atmos Environ 38:6431-6446. doi:10.1016/j.atmosenv.2004.07.031

Hanson PJ, Lindberg SE, Tabberer TA et al (1995) Foliar exchange of mercury vapor: evidence for a compensation point. Water Air Soil Pollut 80:373-382. doi:10.1007/ BF01189687

Hayhoe K, Wake C, Anderson B et al (2008) Regional climate change projections for the Northeast USA. Mitig Adapt Strateg Glob Change 13:425-436. doi:10.1007/s11027007-9133-2

Irvine J, Perks MP, Magnani F, Grace J (1998) The response of Pinus sylvestris to drought: stomatal control of transpiration and hydraulic conductance. Tree Physiol 18:393-402. doi:10.1093/treephys/18.6.393

Jacob DJ, Winner DA (2009) Effect of climate change on air quality. Atmos Environ 43:51-63. doi:10.1016/j.atmosenv. 2008.09.051 
Johnson DW, Lindberg SE (eds) (1992) Atmospheric deposition and forest nutrient cycling. Springer, Berlin

Kalbitz K, Solinger S, Park JH et al (2000) Controls on the dynamics of dissolved organic matter in soils: a review. Soil Sci 165:277-304. doi:10.1097/00010694-20000400000001

Kolka RK, Nater EA, Grigal DF, Verry ES (1999) Atmospheric inputs of mercury and organic carbon into a forested upland/bog watershed. Water Air Soil Pollut 113:273-294. doi:10.1023/A:1005020326683

Laacouri A, Nater EA, Kolka RK (2013) Distribution and uptake dynamics of mercury in leaves of common deciduous tree species in Minnesota, U.S.A. Environ Sci Technol 47:10462-10470. doi:10.1021/es401357z

Leuzinger S, Zotz G, Asshoff R, Körner C (2005) Responses of deciduous forest trees to severe drought in Central Europe. Tree Physiol 25:641-650. doi:10.1093/treephys/25.6.641

Likens GE, Edgerton ES, Galloway JN (1983) The composition and deposition of organic carbon in precipitation1. Tellus B 35B:16-24. doi:10.1111/j.1600-0889.1983.tb00003.x

Lindberg SE, Stratton WJ (1998) Atmospheric mercury speciation: concentrations and behavior of reactive gaseous mercury in ambient air. Environ Sci Technol 32:49-57

Maier CA, Teskey RO (1992) Internal and external control of net photosynthesis and stomatal conductance of mature eastern white pine (Pinus strobus). Can J For Res 22:1387-1394. doi:10.1139/x92-184

Medlyn BE, Barton CVM, Broadmeadow MSJ et al (2001) Stomatal conductance of forest species after long-term exposure to elevated $\mathrm{CO} 2$ concentration: a synthesis. New Phytol 149:247-264. doi:10.2307/3186177

Miller EK, Vanarsdale A, Keeler GJ et al (2005) Estimation and mapping of wet and dry mercury deposition across northeastern North America. Ecotoxicology 14:53-70

Mitchell MJ, Foster NW, Shepard JP, Morrison IK (1992) Nutrient cycling in Huntington forest and turkey lakes deciduous stands: nitrogen and sulfur. Can J For Res 22:457-464. doi:10.1139/x92-060

Natali SM, Sañudo-Wilhelmy SA, Norby RJ et al (2008) Increased mercury in forest soils under elevated carbon dioxide. Oecologia 158:343-354. doi:10.1007/s00442008-1135-6

Obrist D, Johnson DW, Edmonds RL (2012) Effects of vegetation type on mercury concentrations and pools in two adjacent coniferous and deciduous forests. J Plant Nutr Soil Sci 175:68-77. doi:10.1002/jpln.201000415

Plummer DA, Caya D, Frigon A et al (2006) Climate and climate change over North America as simulated by the Canadian RCM. J Clim 19:3112-3132. doi:10.1175/ JCLI3769.1

Pourmokhtarian A, Driscoll CT, Campbell JL, Hayhoe K (2012) Modeling potential hydrochemical responses to climate change and increasing $\mathrm{CO}_{2}$ at the Hubbard Brook Experimental Forest using a dynamic biogeochemical model (PnET-BGC). Water Resour Res 48. doi: 10.1029/ 2011WR011228

Rasmussen PE (1995) Temporal variation of mercury in vegetation. Water Air Soil Pollut 80:1039-1042

Rea AW, Keeler GJ, Scherbatskoy T (1996) The deposition of mercury in throughfall and litterfall in the lake champlain watershed: a short-term study. Atmos Environ 30:3257-3263
Rea AW, Lindberg SE, Keeler GJ (2001) Dry deposition and foliar leaching of mercury and selected trace elements in deciduous forest throughfall. Atmos Environ 35:34533462

Rea AW, Lindberg SE, Scherbatskoy T, Keeler GJ (2002) Mercury accumulation in foliage over time in two northern mixed-hardwood forests. Water Air Soil Pollut 133:49-67

Risch MR, DeWild JF, Krabbenhoft DP et al (2012a) Litterfall mercury dry deposition in the eastern USA. Environ Pollut 161:284-290

Risch MR, Gay DA, Fowler KK et al (2012b) Spatial patterns and temporal trends in mercury concentrations, precipitation depths, and mercury wet deposition in the North American Great Lakes region, 2002-2008. Environ Pollut 161:261-271. doi:10.1016/j.envpol.2011.05.030

Schmeltz D, Evers DC, Driscoll CT et al (2011) MercNet: a national monitoring network to assess responses to changing mercury emissions in the United States. Ecotoxicology 20:1713-1725. doi:10.1007/s10646-011-0756-4

Schuster PF, Shanley JB, Marvin-Dipasquale M et al (2008) Mercury and organic carbon dynamics during runoff episodes from a northeastern USA watershed. Water Air Soil Pollut 187:89-108. doi:10.1007/s11270-007-9500-3

Selvendiran P, Driscoll CT, Bushey JT, Montesdeoca MR (2008) Wetland influence on mercury fate and transport in a temperate forested watershed. Environ Pollut 154:46-55. doi:10.1016/j.envpol.2007.12.005

Sheehan KD, Fernandez IJ, Kahl JS, Amirbahman A (2006) Litterfall mercury in two forested watersheds at Acadia National Park, Maine, USA. Water Air Soil Pollut 170:249-265. doi:10.1007/s11270-006-3034-y

St. Louis VL, Rudd JWM, Kelly CA et al (2001) Importance of the forest canopy to fluxes of methyl mercury and total mercury to boreal ecosystems. Environ Sci Technol 35:3089-3098. doi:10.1021/es001924p

USEPA (1998) Method 7473: Mercury insolids and solutions by thermal decomposition, amalgamation, and atomic absorption spectrometry. Washington, DC

USEPA (2002) Method 1631, Revision E: Mercury in water by oxidation, purge and trap, and cold vapor atomic fluorescence spectrometry. Washington, DC

Wiener JG, Krabbenhoft DP, Heinz GH et al (2003) Ecotoxicology of mercury. In: Hoffman DJ et al (eds) Handbook of ecotoxicology, 2nd edn. Lewis Publishers, Boca Raton, pp 409-464

Witt EL, Kolka RK, Nater EA, Wickman TR (2009) Influence of the forest canopy on total and methyl mercury deposition in the boreal forest. Water Air Soil Pollut 199:3-11. doi:10. 1007/s11270-008-9854-1

Yu X, Driscoll CT, Huang J et al (2013a) Modeling and mapping of atmospheric mercury deposition in Adirondack Park, New York. PLoS ONE 8:e59322. doi:10.1371/journal. pone.0059322

Yu X, Driscoll CT, Warby RAF et al (2013b) Soil mercury and its response to atmospheric mercury deposition across the northeastern United States. Ecol Appl. doi:10.1890/130212.1 